Middle East Journal of Science(MEJS)

journal homepage: http://mejs.ineseg.org/

\title{
DNA DAMAGE MECHANISMS OF ANTI-CANCER DRUGS
}

\section{Bircan Çeken Toptanci ${ }^{1}$, Göksel Kizil ${ }^{2}$, Murat Kizil ${ }^{* 3}$}

${ }^{1}$ Dicle Üniversitesi, Fen Fakültesi, Kimya Bölümü, 21280 Diyarbakır, Türkiye

${ }^{2}$ Dicle Üniversitesi, Fen Fakültesi, Kimya Bölümü, 21280 Diyarbakır, Türkiye

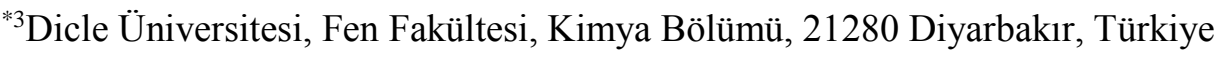

*muratk@dicle.edu.tr

Organic molecules with DNA-damage ability are of great potential in the development of medicine, toxicology, biochemistry, organic chemistry, biotechnology and gene therapy. DNA damaging agents have historically played a central role in cancer therapy. Even as new approaches to cancer therapy become available, it seems likely that there will be a continued need for the study and development of novel DNA damaging cytotoxins. These agents will see continued use due to their well-establised role in treating various types of cancer and because many of the new approaches to cancer treatment such as immunoteraphy and modulation of the cell cycle are most effective when used in combination with traditional cytotoxins. It is commonly believed that natural products which display potent biological activity are results of natural selection. DNA-damaging natural products frequently possess potent cytotoxic, cytostatic or mutagenic properties and, in nature, may serve as either offensive or defensive weapon in the struggle for survival. Natural products constitute a vast library of organic compounds that can serve as a useful force. A practical reason for the longstanding interest in DNA-damaging natural products is the fact that the cytotoxic or cytostatic effects of these agents sometimes endow them with useful medicinal properties, especially as potential anticancer therapeutics. Several DNAdamaging natural products are currently in use for the treatment of various cancers and others have served as lead compounds in the development of therapeutic agents. Many anti-cancer agents work by alkylating DNA while others destroy DNA by radical chemistry, starting either (i) by abstracting a hydrogen atom from a deoxyribose sugar or (ii) by adding to the alkene pi bond in a base.DNA-damaging agents can be placed into four chemical categories: Intercalators, alkylating agents, DNA strand breakers and groove binders. In this review, DNA damage mechanisms of anti-cancer drugs are 
discussed.Finally, natural products with extremely potent biological activities sometimes reveal unforeseen biological pathways and these compounds can become useful tools for elucidating the details of complex life processes.

Key words: Natural Products, DNA Damage, Anti-Cancer Agents

\section{ANTİ-KANSER İLAÇLARININ DNA HASAR MEKANİZMALARI}

DNA'ya zarar veren maddeler Tipta, Toksikolojide, Biyokimya, Organik Kimya, Biyoteknoloji ve Gen terapisinin gelişiminde büyük bir öneme sahiptirler. Bu tür maddeler, kanser terapisinde de önemli bir rol oynamaktadırlar. Bu nedenlerden dolayl, DNA'ya bağlanabilen veya onunla reaksiyona girebilen küçük moleküllerin izolasyonu ve sentezine yönelik çalışmalara ciddi bir yönelme olmuştur. Bu tür ajanların bazı kanser türlerinin tedavisindeki rolü iyice anlaşılmıştır. İmmünoterapide ve hücre döngüsünün modülasyonu gibi kanser tedavisindeki yeni yaklaşımlarda, geleneksel sitotoksinlerin rolü, bu tür moleküllerin kullanılmasına uzun süre devam edeceği gözükmektedir.Bu tür ajanların çeşitli kanser türlerinin tedavisindeki rolü iyice anlaşıldığından, immünoterapi ve hücre döngüsünün modülasyonu gibi kanser tedavisindeki yeni yaklaşımların geleneksel sitotoksin moleküller ile birlikte kullanıldığında daha etkili olmasından, bu tür ajanlara daha uzun süre ihtiyaç duyulacağı anlaşılmaktadır.Biyolojik aktivite gösterme potansiyeline sahip doğal ürünlerin, doğal seleksiyon sonucu oluştuğuna inanllır. Doğal ürünlerin neden olduğu DNA hasarl genelde sitotoksik, sitostatik veya mutajenik özellikler gösterir. Bundan dolayı hayatta kalma savaşında ya öldürücü ya da koruyucu silah olarak davranabilirler. Doğal ürünler yararlı organik bileşikler içinde geniş bir yer kaplarlar. DNA'ya zarar veren doğal ürünlere ilgi onlarm sitotoksik ve sitostatik etkilerinden kaynaklanır. Bu etkilerden dolayı DNA'ya zarar veren birçok doğal ürün çeşitli kanser türlerinin tedavisinde kullanılır. Bazllarl ise terapötik ilaçlar için öncü olmuşlardır. DNA'nın kovalent modifikasyon mekanizmalar iki kategoride siniflandirılır: (i) Elektrofillerin DNA'nın nükleofilik kisimlarla reaksiyonu, ya da (ii) radikallerin DNA ile reaksiyonu. DNA ile etkileşen ilaçları dört ana başlık altında toplayabiliriz: interkalatörler, alkilleyici ajanlar, DNA zincirini kıranlar ve DNA oluğuna bağlananlar. Bu derlemede, Anti-kanser ilaçlarının DNA hasar mekanizmaları tartışılmıştır.Sonuç olarak yüksek biyolojik aktiviteleri olan doğal ürünler bazen beklenmedik yollarla biyolojik etki gösterebildikleri için, kompleks yaşam sürecini açıklamak için yararlı olabilirler.

Anahtar Kelimeler: Doğal ürünler, DNA hasarı, Anti-Kanser Ajanlar 


\section{Giriş}

Dünyanın en önemli sağlık sorunlarından biri kanser olup ülkemizde de çok sıklıkla görülmektedir. 2002 yılında Dünya Sağlık Örgütü’nün verdiği rakamlara göre tüm dünyada 11 milyon insana farklı türde kanser teşhisi konulmuş, bunların 7,1 milyonu yaşamını yitirmiştir. 2020 yılında 16 milyon insana çeşitli tipte kanser teşhisi konulacağı öngörülmektedir. Bu rakamlar dünyada kanser teşhisi ve tedavisinin ne kadar önemli olduğunu ortaya koymaktadır.

Ülkemizde 1970'li yıllarda sebebi bilinen ölümler sırasında dördüncü sırada yer alan kanser, son y1llarda kardiyovasküler sistem hastalıklarından sonra ikinci sıraya yükselmiştir. Erken tanı konulduğu takdirde önlenebilir ve tedavi edilebilir bir hastalık olan kanserin bu denli hızlı artış göstermesi ülkemizde kanserin teşhisi ve tedavisi ile etkin mücadele edilmesini gerekli kılmaktadır. Kanser çalışmaları oldukça büyük önem kazanmış olup, kanser teşhisi ve tedavisinde kullanılacak moleküllerin sentezi ve uygulamaları güncel araştırma konularının içinde olmuştur. Günümüzde, kanserin tedavisinde kemoterapi ilacı olarak kullanılan moleküllerin önemli bir dezavantajı seçici olmamalarıdır. Bunlar, tümör hücrelerinin yanında sağlıklı hücrelerinde DNA yapısını bozar ve bazen sağlam hücrelerde tamiri mümkün olmayan yan etkilere sebep olurlar.

Yeni sentezleri yapılan moleküllerde temel hedef; sadece tümör hücrelerine karşı seçicilik sonucu düşük zehir etkisidir. Son yıllarda gelişen teknoloji ile birlikte tümör hücrelerine karşı yüksek seçicilik gösteren bileşikler sentezlenmiştir. Bu moleküllerin büyük bir kısmının hücre içinde ve dışında tümör hücrelerine karşı aktif olduğu belirlenmiş olup farklı tedavi yöntemlerinde kullanılmaktadırlar. Farklı yöntemlerin ve moleküllerin kullanımı, kanserin türüne ve oluşum evresine bağlıdır.

Kanser, hücrelerin kontrolsüz çoğalmasıyla ve bu hücrelerin başka bir bölgeye göç etme yetenekleriyle bu bölgelerde ikincil tümörlerin meydana gelmesiyle sonuçlanır. Gelişmiş ülkelerde ölümün ikinci ana sebebi olmakla beraber gelişmekte olan ülkelerde de yetişkin ölümlerinin üç ana sebeplerinden biridir. DNA'yı hedef alan antikanser ajanlar klinik kullanım için en etkili ilaçlardır ve kanser hastalarının hayatta kalma sürelerini anlamlı olarak arttırırlar. Klinik olarak kullanılan çok sayıda antikanser ilaç, antitümör etkilerini DNA'da kovalent veya kovalent olmayan bağlanma yolu ile hasar oluşturarak meydana getirir.

Yaşamın kodu olan Deoksiribonükleik asit (DNA), anne ve babadan evlatlarına aktarılan genetik bilgilerin saklanmasına uygun olması için, birbirini tamamlayan anti paralel iki sarmal zincirden oluşmuştur[1,2] DNA, her nükleotitinde 2-Deoksiriboz şekeri, bir fosfat grubu ve bir azotlu baz bulunan, polinükleotid zincirlere sahiptir. Azotlu bazlar pürinlerden (adenin "A" ve guanin "G") ve pirimidinlerden (timin "T" ve sitozin "S") oluşmaktadır (Şekil 1.1.). Deoksiriboz şekeri ve fosfat grubu azotlu bazlara bir iskelet oluşturur, böylece deoksiriboz birimine direkt olarak bağlanmasını sağlar[3] Her azotlu baz farklı bir yapıya ve yapılarındaki elektron alan veya veren gruplardan dolayı spesifik hidrojen bağı oluşturma kapasitesine sahiptir. A ile $T$ ve $G$ ile $S$ bağlanır (Şekil 1.2.), bundan dolayı spesifik DNA örneklerinde her zaman A miktarı T ve G miktarı da S miktarına eşittir[4]. Baz çiftlerinin uzayda düzeni büyük ve küçük olukların oluşmasını (Şekil 1.3.) sağlar[5]. Moleküler seviyede her oluğun çevresi farkl111k gösterir [6]. Büyük oluk birden fazla etkileşim alanı gösterir, buda ilaçlarla nispeten daha fazla kuvvetli bağ oluşturmasını sağlamaktadır[7]. 11,6 ̊̊ genişliğe ve 8,5 Å derinliğe sahiptir[8]. Büyük oluk hacimli moleküllerin kolayca bağlanmasına izin vermektedir[9]. Diğer taraftan 
küçük oluklar daha az bağlantı alanı sağlarlar ve daha küçük boyuttadırlar, derinlikleri 8,2 A kadardır. Bununla beraber küçük olukların en yararlı özellikleri, genellikle korumasız olduklarından dolayı, küçük ilaç moleküllerinin saldırılarına açık olmalarıdır. Birçok antibiyotik ve antikanser ilaçlar da küçük moleküller olduğundan küçük oluklar bunların ana bağlanma kısımlarıdır[10,11].<smiles>Nc1ncnc2c1ncn2-c1nccs1</smiles>

Adenin

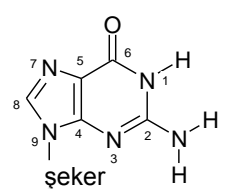

Guanin<smiles>CCn1cc(C=O)c(=O)[nH]c1=O</smiles>

Timin<smiles></smiles>

Sitozin
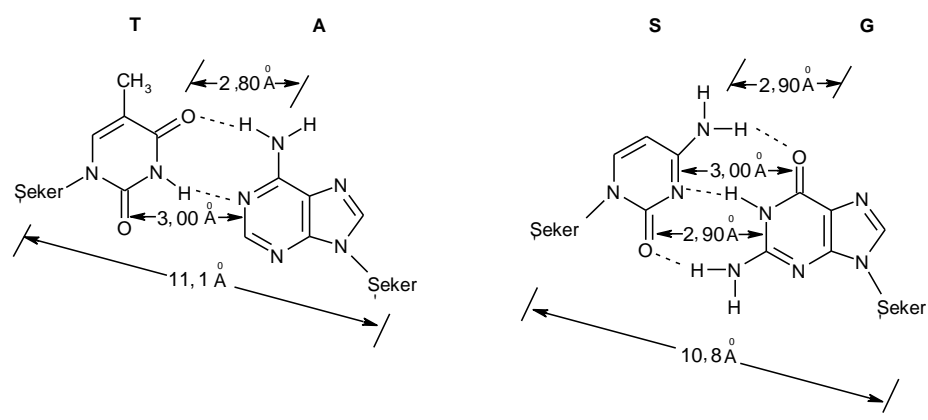

Şekil 1.2. A-T ve S-G arasındaki Watson-Crick Hidrojen Bağları
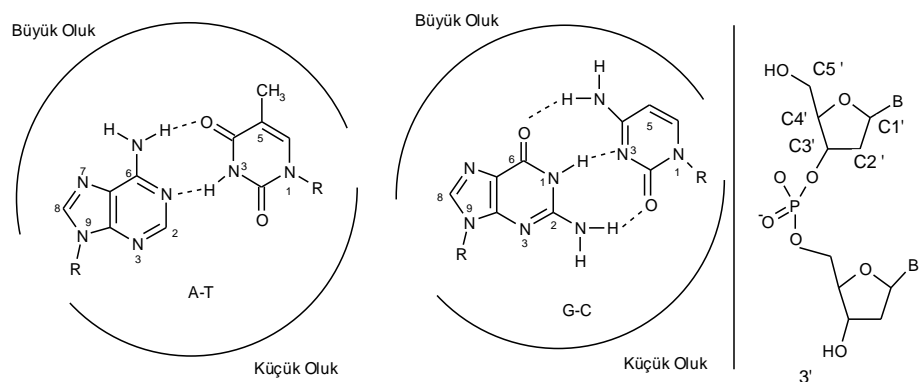

R= DNA Zinciri

B=DNA Baz

Şekil 1.3. Pürin ve Pirimidin Hidrojen Bağ Çiftleri Arasında Oluşan Büyük ve Küçük Oluklar; Şeker Fosfat Omurgası

Normal hücrelerin tümör hücresine dönüşmesinde mekanizmayı anlamaya odaklanmış araştırmalar, farklı tip mutasyonların[12,13] ve DNA'nın hücre çekirdeği içerisinde yeniden düzenlenmesinin, gen ekspresyonunu ve diğer biyokimyasal süreci etkileyebileceğini göstermiştir. Belirgin olarak onkogenez ile sağl1klı hücre kanser hücresine dönüşmektedir[14]. Kanserin şartları ve evresine bağlı olarak farkl1 tip tedaviler kullanılmaktadır. Cerrahi, radyoterapi, kemoterapi ve immünoterapi bunlardan bazılarıdır. Kemoterapinin amacı kimyasalları kullanarak hücrelerin, hücre büyümesi ve hücre bölünmesi gibi bazı fonksiyonlarını durdurarak tümör hücresini öldürmeyi amaçlamaktadır[15]. Cisplatin, oxaliplatin gibi 
platinyum kompleksleri, mustine, klorambusil ve melphalan (L-PAM) gibi bazı azot hardalları, iyi bilinen geleneksel anti-kanser ilaçlarından bazılarıdır[17].

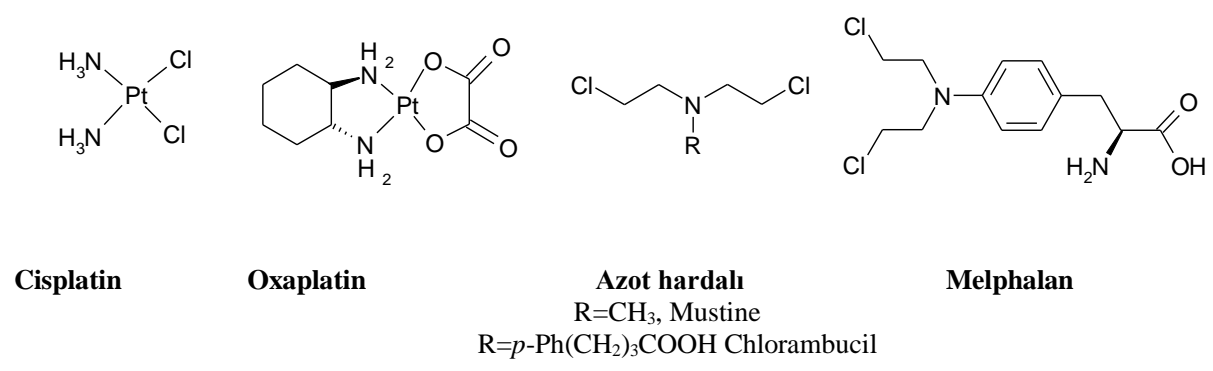

Günümüzde klinik olarak kullanılan anti-kanser ilaçlarda seçici olmama, metastaz veya ikincil gelişmeleri kontrol yeteneğinin olmaması gibi problemler bulunmaktadır[18]. Bunlara ek olarak, kanser doğasının heterojenik olmasının nedeni 100'den fazla kanser çeşidi olmasıdır[19]. Kanserin doğasına, yerine ve seviyesine bağlı olarak her problem için spesifik ilaçlara ihtiyaç bulunmaktadır. Ayrıca kanserli hücrelerde birden fazla ilaca karşı direnç oluşması, yani başlangıçta bir spesifik ilaç ile baskılanırken bu ilaca karşı direnç gelişmesi fazlaca görülen bir problem olarak karşımıza çıkmaktadır[201,21]. Bu problemlerin üstesinden gelebilmek için daha etkili ve seçici ilaçlara ihtiyaç duyulmaktadır. Kanseri ve kemoterapiyi anlamada ileriye gidilmesi,[22] tümör hücrelerinin gelişimini kontrol altına alma potansiyelleri olan DNA dizisini spesifik, yeni ajanların bulunması ile sonuçlanmıştır[23].

Bu anti-kanser ilaçların DNA ve DNA'ya bağlı proteinler üzerinde bazı seçici bölgeler ile kuvvetli etkileşimleri vardır[24]. Bir anti-kanser ligand DNA'yı hedef aldığı zaman sitotoksik etkisinin bir sonucu olarak DNA'nın normal aktivitesini değiştirerek hücre ölümüne neden olur[25].

DNA'ya bağlanma moduna bağlı olarak anti-kanser ilaçlar iki ana katagoriye ayrılırlar[26]: mitomycin C [27], anthramycin, ecteinascidin türevleri (ET-743) ve bleomycin A2[28] gibi DNA'da ve fonksiyonlarında kalıcı hasara neden olan kovalent bağlananlar[29], ve fiziksel olarak DNA ile etkileşen ve etkilerini geçici olarak DNA fonksiyonlarını değiştirerek gösteren[30] (distamycin ve netropsin gibi) kovalent olmayan şekilde bağlananlar. Kovalent olmayan etkileşimler kendi aralarında üç büyük sınıfa da ayrılabilirler [31], bunlar elektrostatik etkileşimler, interkalasyon ve oluklara bağlanmadır.

\section{Kovalent DNA Modifikasyonunun Genel Mekanizması}

DNA'nın kovalent modifikasyon mekanizmaları iki kategoride sınıflandırılır: (i) Elektrofillerin DNA'nın nükleofilik kısımlarla reaksiyonu, ya da (ii) radikallerin DNA ile reaksiyonu.

Elektrofiller DNA yapısındaki farklı nükleofilik kısımlarla etkileşebilir. Kimyasal yapılarına bağlı olarak DNA'nın belli nükleofilik kısımlarına selektivite gösterirler. DNA'da guaninin N-7, N-3 ve exosiklik N2 amino grubu ile adeninin N-7 ve N-3 kısımları doğal ürünlerle en çok modifikasyona uğrayan kısımlardır (Şekil 1.3) [32].

Pürin kalıntılarının N-7 ya da N-3 pozisyonundan elektrofilik modifikasyonu glikozidik bağın zayıflamasıyla sonuçlanır. Bunun sonunda abazik bölge (1) oluşur ve nötral şartlarda bu bölgeler hidrolizlenerek DNA kesimi gerçekleşir (Şekil 1.4). DNA bazlarındaki exosiklik azot ve karbonil oksijenleri ya da DNA omurgasındaki fosfat oksijenleri ile elektrofik türleri reaksiyonu genellikle kararlı ürünler oluşturur [33] 
<smiles></smiles><smiles>C=CC1CC[C+]2C(O)CC(O)C21</smiles><smiles>CC(C)C(O)CC=O</smiles>

\section{Şekil 1.4. Abazik Bölge Oluşumu ve DNA Kesimi}

Bazı radikal türleri DNA ile değişik pozisyonlarda etkileşirler. DNA'nın radikaller tarafından hasara uğratılmasında en önemli yol deoksiribozdan hidrojen atomu koparılmasıdır[34]. Deoksiriboz şekerinden hidrojen atomu koparılması şeker fosfat omurgasının kırılmasına sebep olur (Şekil 1.5) [35]. Şeker fosfat omurgasına etkimeye ek olarak bazı radikaller de DNA bazlarıyla etkileşirler[36]. Bu reaksiyonlar şeker fosfat omurgasının kırılmasına sebep olmazlar fakat DNA yapısındaki modifikasyonlar biyolojik olarak önemlidirler. Spesifik bir bağlanma olmadığı zaman DNA kesimi genelde küçük dizilerle ya da baz özgünlügüyle meydana gelir. Bunun aksine alkilleyici ajanlarla DNA kesimi bir veya daha fazla DNA bazı için selektivite gösterir[37].

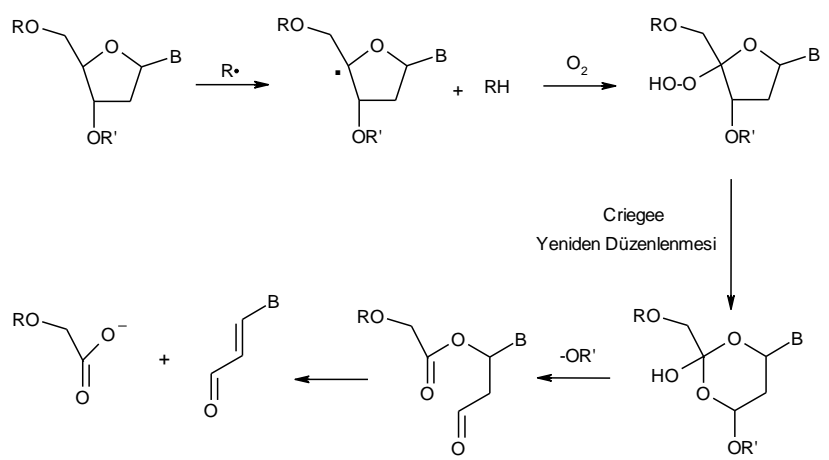

Şekil 1. 5. DNA Şekerinden Hidrojen Atomu Koparılması (R, $R^{\prime}=$ DNA omurgası) 


\subsection{DNA İle Etkileşen İlaçlar}

DNA ile etkileşen ilaçları üç ana başlık altında toplayabiliriz: DNA' daki baz çiftleri arasına girerek $\alpha$ heliks yapıyı bozan interkalatörler; DNA bazlarıyla kovalent olarak bağlanan alkilleyici ajanlar ve radikal oluşturarak DNA polinükleotid zincirinde kesime neden olan DNA zincirini kıranlar[38].

\subsection{DNA İnterkalatörleri}

Düz, genellikle aromatik ya da heteroaromatik moleküller $\alpha$-heliks yapıdaki baz çiftleri arasına girerek DNA' ya bağlanırlar ve baz çiftleriyle kümelenirler. İnterkalasyonda etkin olan kuvvetler yük transfer kuvvetleridir, fakat hidrojen bağları ve elektrostatik kuvvetler de kararlılıkta rol oynarlar. İlk olarak 1961 yılında Lerman tarafından açıklanan interkalasyon, ilacın heliksin eksenine rijit bir şekilde, dik olarak kovalent olmayan bağlanmasıdır. Bu da baz çiftlerinin düşey olarak ayrılmasına sebep olur, dolayısıyla şeker fosfat omurgası bükülür ve heliksin yapısı bozulur. Görünüşe göre interkalasyon güçle ilgilidir. Baz çifleri ile interkalatör molekülü arasındaki van der Waals kuvvetleri, birbirleriyle kümelenmiş baz çiftleri arasındaki van der Waals kuvvetleri'nden daha güçlüdür[38]. Etidyum bromür en iyi bilinen DNA interkalatörlerindendir (Şekil 1.6).
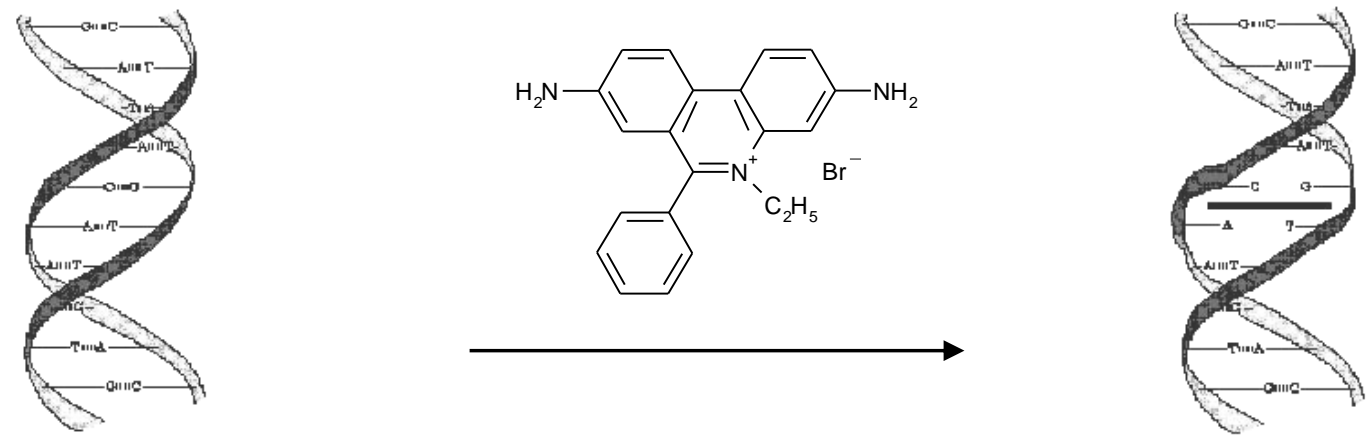

\section{Şekil 1.6. Etidyum Bromürün B-DNA’ya İnterkalasyonu}

İnterkalasyon Watson-Crick hidrojen bağlarını kırmaz, heliks yapıyı deforme eder. Direk DNA hasarına sebep olmaz, heliks yapıda konformasyon değişikliğine yol açar. DNA interkalatörlerini üç gruba ayırabiliriz. Akridinler, aktinomisinler ve anthrasiklinler [38].<smiles>[R]c1cc(N(C)S(C)(=O)=O)ccc1Nc1c2cccc([R])c2nc2c([R])cccc12</smiles>

Amsacrine, $\mathbf{R}=\mathbf{R}^{\prime}=\mathbf{H}$

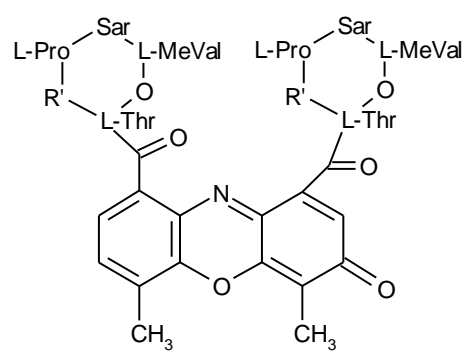

Actinomycin D, R=R'= D-Val 


\subsection{Alkilleyici Ajanlar}

DNA alkilleyicileri ile interkalatörleri arasındaki fark bağlanma şekilleridir. DNA interkalatörleri DNA ile kovalent olmayan bağlarla bağlanırken, alkilleyici ajanlar kovalent bağlarla bağlanırlar. Kanser kemoterapisinde kullanılan en önemli alkilleyici ajanlar azot hardalları, etileniminler, metanosülfonik asit esterleri ve platin komplekleridir [38].

Sülfür hardalı I. ve II. Dünya savaşlarında kullanılmış çok toksik sinir gazıdır. I. Dünya Savaşında sülfür hardalıyla ölen askerlerin otopsileri sonucu lökopeni (düşük beyaz kan hücresi), kemik iliği aplazi, lenf dokularında bozunma, ve gastrointestinal sistemde ülser saptanmıştır. Bu lezyonlar sülfür hardallarının hızlı bölünen hücrelere etkili olduğu sonucuna götürmüş ve antitümör etkileri olabileceği düşünülmüş. 1931 yılında sülfür hardalı insanlarda tümör hücresine enjekte edilmiş, fakat bu işlemin sistematik kullanım için çok toksik olduğu artaya çıkmıştır. Gillman ve diğer kimyacılar daha az toksik olan azot hardallarının antitümör etkisini incelemişler. 1942 yılında azot hardalının klinik denemeleri başlamıştır. Çalışma II. Dünya savaşı süresince devam etmiştir. Azot hardallarının 1946 yılından beri kanser tedavisinde kullanıldığı bilinmektedir. Bu çalışma modern kanser kemoterapisinin başlangıcı olmuştur [38].<smiles>ClCCSCCCl</smiles>

Sülfür hardalı<smiles>[R]N(CCCl)CCCl</smiles>

Azot hardal $\mathbf{R}=\mathrm{CH}_{3}$

Ross'a göre biyolojik alkilleyici ajanlar fizyolojik koşullarda (pH 7.4, 37 oC, sulu çözelti) hidrojen atomuyla alkil grubunun yerini değiştirebilen moleküllerdir. DNA için en iyi reaktif olan nükleofilik kısımlar N-7 guanin > N-3 adenin > N-1 adenin > N-1 sitozin sıralamasıdır [39].

Azot hardalları bifonksiyonel alkilleyici ajanlardır, yani iki tane elektrofilik kısımları vardır. DNA bazlarını zincir içi veya zincirler arası bağlayabilirler. Azot hardallarının alkilasyonu şekil 1.7'de gösterilmiştir. Azot hardalları komşu iki guanin bazını N-7 pozisyonundan alkilleyerek iki zinciri birbirine bağlayabilirler (Şekil 1.8) [38].

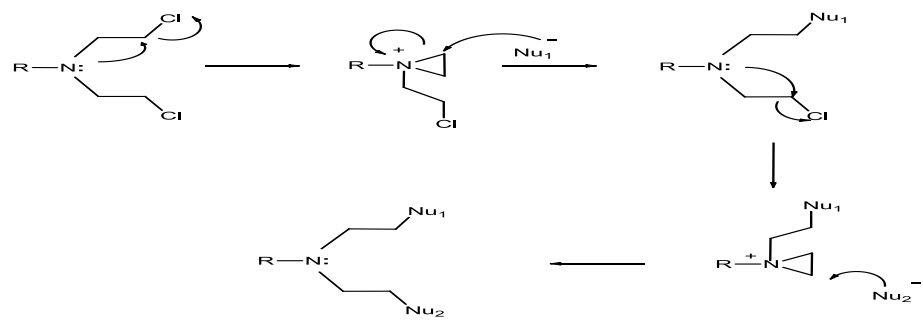

Şekil 1. 7. Azot Hardallarıyla Alkilasyon 


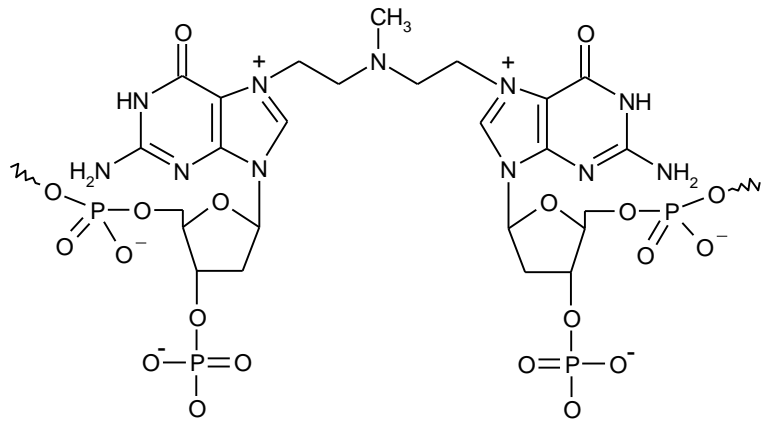

Şekil 1.8. Azot Hardallarının Neden Olduğu Çapraz Bağlanma

Chatterji, ve arkadaşları Streptomyces'ten elde edilen doğal ürün leinamycinin çift zincirli DNA yapısını alkilleme mekanizmasını araştırmışlar. Leinamycinin tipik bir interkalasyon ajanı olduğunu ve tek zincirli DNA'yı alkillemediğini, tiyol ile aktive edildiğinde leinamicynin konsantrasyona bağlı olarak supercoiled plazmid DNA'yı open circular forma dönüştürdüğünü tespit etmişlerdir [39].<smiles>CC[C@]1(CC(=O)NC(C)c2nc(/C=C\C=C/C(=O)C(O)/C=C(\C)C(=O)O)cs2)C(=O)SS(=O)[C@@]1(C)O</smiles>

Diğer alkilleyici ajanlar etileniminler, metanosülfonik asit esterleri, azot kaynaklılar ve platin kompleksleridir [38].

\subsection{DNA Zincirini Kıranlar}

DNA ile etkileşen ilaçların bazıları başta DNA interkalatörleri gibi bazların arasına girerler daha sonra uygun koşullarda radikalleri oluştururlar. Bu radikallerin DNA ile etkileşimi DNA zincirinin kırılmasına sebep olur.

\subsubsection{Antrasiklin Antitümör Antibiyotikleri}

DNA intekalatörleri olan antrasiklinler aynı zamanda oksijene bağlı DNA hasarına da neden olurlar[39]. 


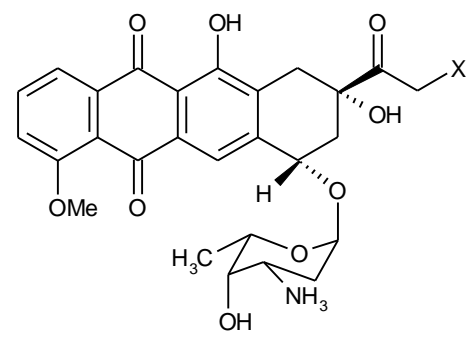

Doxorubicin, $\mathrm{X}=\mathrm{OH}$

\subsubsection{Bleomycin}

Bleomycin 1966 y1lında Streptomyces verticillus’tan izole edilmiş bir antitümör antibiyotiğidir.

\section{Bleomycin}

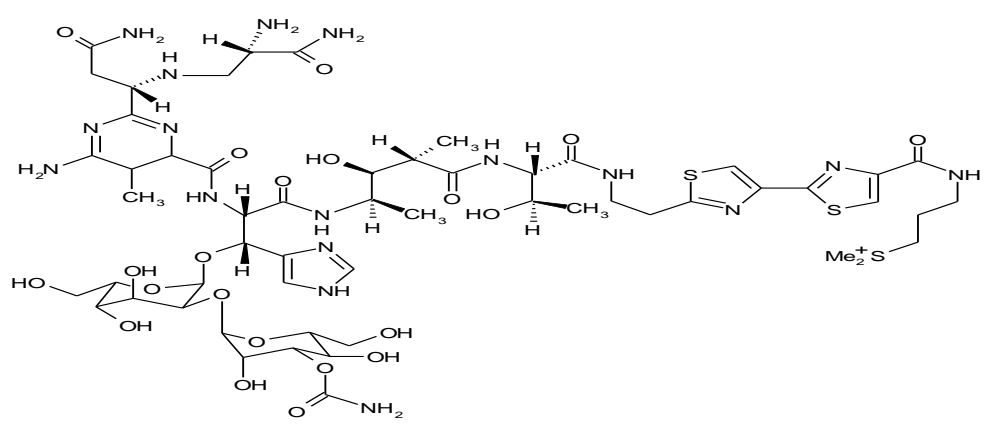

\section{Bleomycin-Fe II Kompleksi}

Bleomycinde pirimidin, $\beta$-aminoalanin ve $\beta$-hidroksiimidazol Fe(II) ile DNA kesim etkisi olan kararlı bir kompleks oluşturur. NMR ve hidrodinamik çalışmalar yapıdaki bithiazolun interkalasyon etkisi olduğunu, fakat bu interkalasyonun klasik interkalatörler (etidyum bromür vb.) kadar etkisi olmadığını göstermiştir. Bazı çalışmalar bithiazolun tam interkalete olmadığını fakat DNA yapısındaki oluklara bağlandığını göstermiştir.Yapıdaki sülfonyum iyonunun fosfat grubu ile elektrostatik olarak etkileşme olasılığı vardır. Glikoz, mannoz ise bleomicinin bazı kanser hücrelerinde selektif olarak birikiminden sorumlu olabilirler, fakat DNA kesiminde rol almazlar .

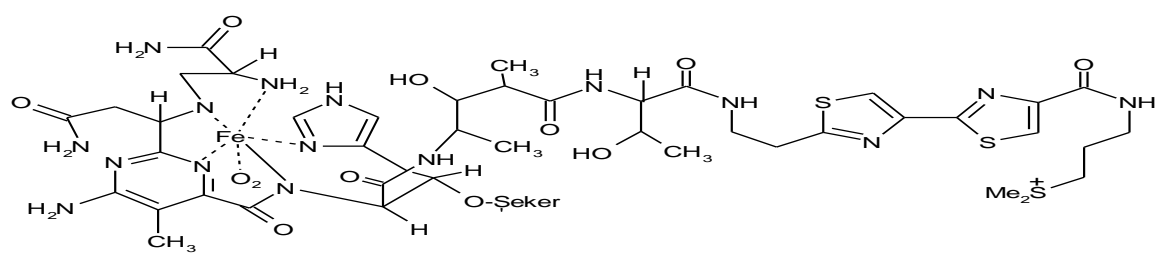


DNA kesim ürünlerinin incelenmesiyle, kesimin genellikle DNA zincirinin 3' ucundaki pürin nükleotidine bağlı olan pürimidin nükleotinin $4^{\prime}$ karbon atomundan hidrojen koparılmasıyla gerçekleştiği anlaşılmıştır .

\subsubsection{Enediyen Antibiyotikleri}

1965 yılında izole edilen neocarzinostatin dışındaki enediyen antibiyotikleri esperamicin, calicheamisin, ve dynemicin A 1980'lerin sonlarına doğru çeşitli mikroorganizmalardan izole edilmişlerdir. Yapılarında en az bir çift bağ ve iki üçlü bağ bulundurdukları için enediyen antitümör antibiyotikleri olarak anılırlar. Bu tür moleküller DNA zincirinde küçük olukta interkalasyon yaparlar daha sonra tiyol (SR) veya NADPH gruplarıyla aktive edilerek DNA zincirini kesen radikallerini oluştururlar .

\subsubsection{Neocarzinostatin}

1965 yılında Sterptomyces carzinostaticus'tan izole edilmiştir. Bilinen en eski enediyen antibiyotiğidir. Zinostatin olarak da bilinir. Tiyol tarafından aktive edilerek Bergman, yeniden düzenlenmesiyle diradikal oluşturur (Şekil 1.9). Oksijen varlığında iki farklı mekanizma ile DNA kesimi (Şekil 1.10) gerçekleşir.

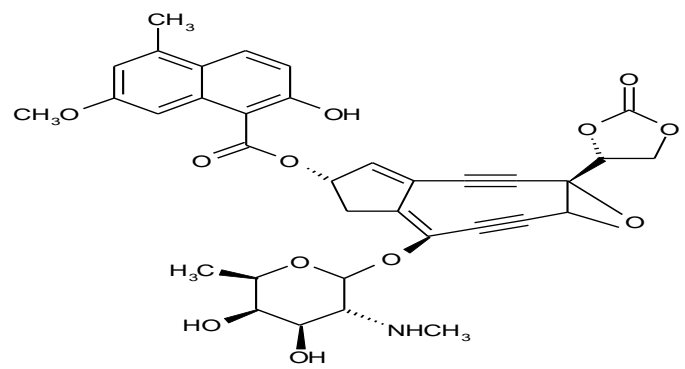

\section{Neocarzinostatin}

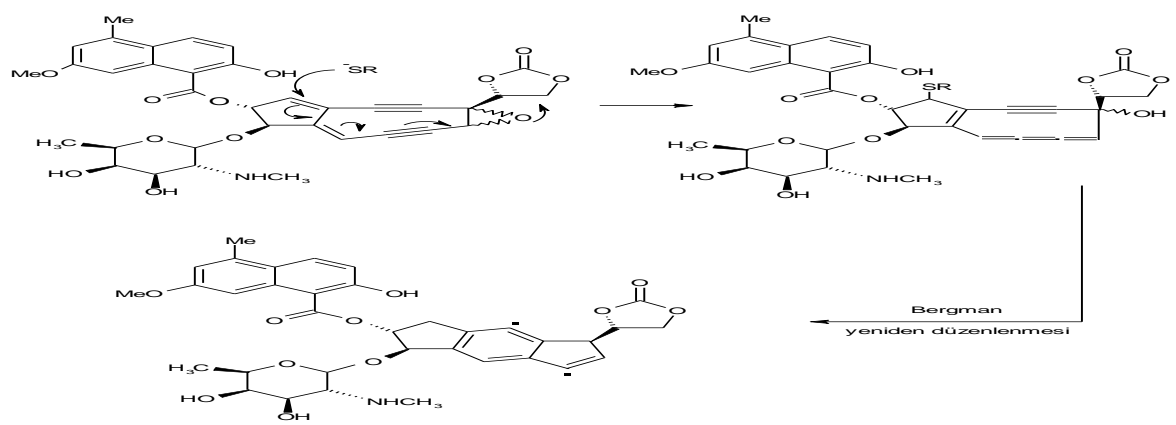

Şekil 1.9. Neocarzinostatinin Tiyol İle Aktivasyonu 


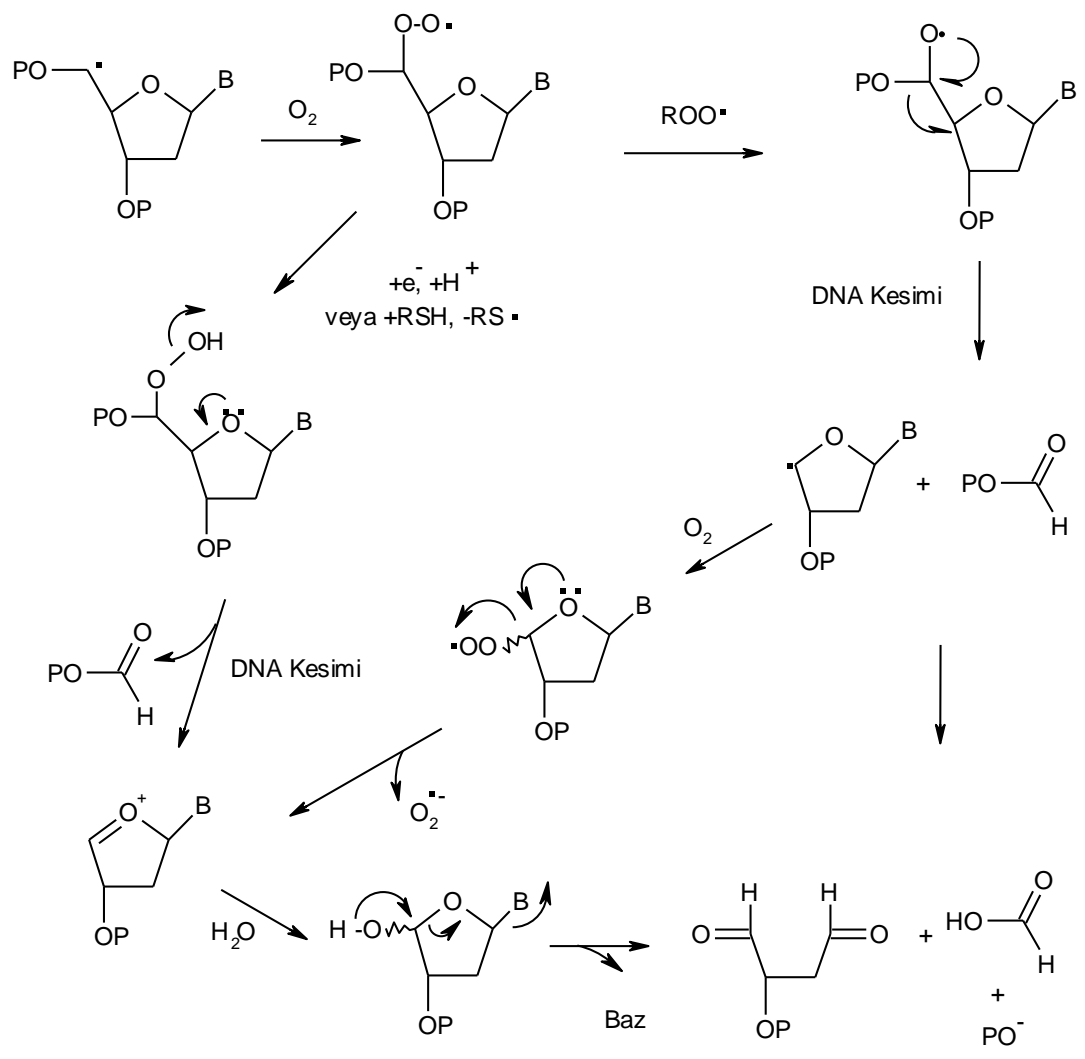

Şekil 1.10. Aktive Edilmiş Neocarzinostatin ve Diğer Enediyen Antibiyotikleri Tarafından DNA Kesim Mekanizması

\subsubsection{Esperamicin ve Calicheamicin}

Esperamicin ve calicheamisin antitümör antibiyotiğidirler. Esperamicin Actinomadura verrucosospora, calicheamicin ise Micromonospora echinospora ssp. calichensis toprak örneklerinden izole edilmişlerdir. Neocarzinostatin gibi diradikal oluşturarak DNA kesimine sebep olurlar .

\section{Esperamicin}

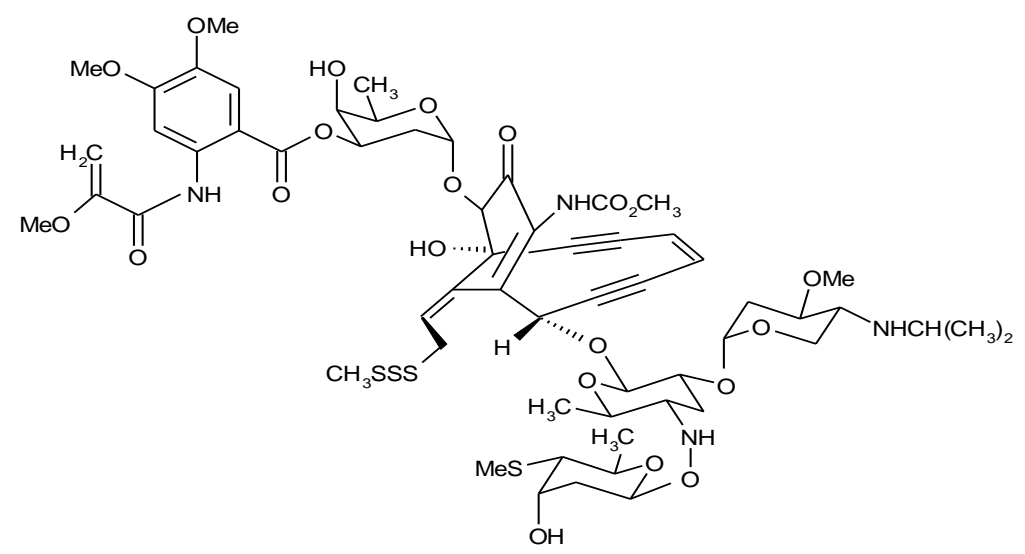




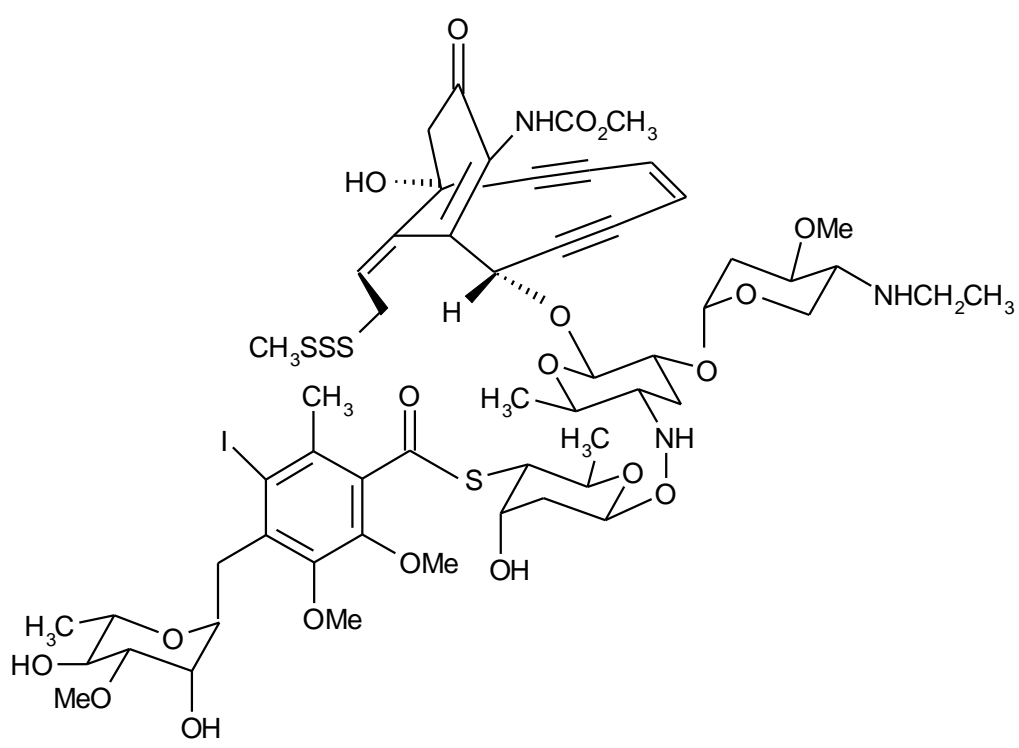

Calicheamicins

\subsubsection{Dynemicin A}

1989 y1lında Micromonospora chersina'dan izole edilen dynemicin hem enediyen hem de antracycline antibiyotiklerinin yapısal olarak kombinasyonudur. Yapısındaki antraquinonun DNA dubleksi arasına girerek interkalasyona sebep olduğu tahmin edilmektedir. Daha sonra neocarzinostatin gibi diradikal oluşturarak DNA şekerinden hidrojen atomu kopararak DNA kesimine sebep olurlar.

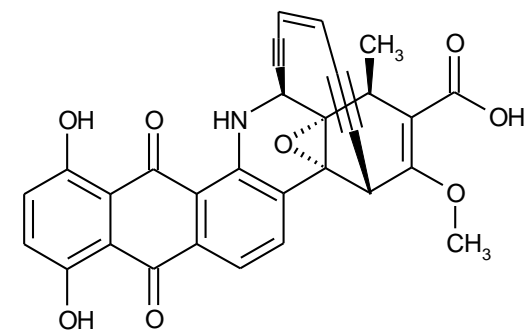

\section{Dynemicin A}




\subsection{DNA Oluklarına Bağlananlar}

Büyük ve küçük oluğa bağlanan ligandlar, baz çiftlerinde bulunan fonksiyonel gruplar ile doğrudan hidrojen bağı yaparlar. Genellikle küçük moleküller DNA küçük oluğuna bağlanırlar. (+)-CC-1065, Duocarmycin, Netropsin ve Distamycin (Şekil 1.9.). DNA oluğuna bağlanan antikanser antibiyotiklerdir.

CC-1065, (+)-Duocarmycin A ve SA'nın, DNA küçük oluğuna bağlanıp DNA'da selektif alkilasyon yaparak (Şekil 1.11.) biyolojik etki gösteren son derece etkili antitümör antibiyotiklerin bir sınıfinı temsil ettiği bilinmektedir. CC-1065 antibiyotiği bilinen en toksik antitümör antibiyotiktir .

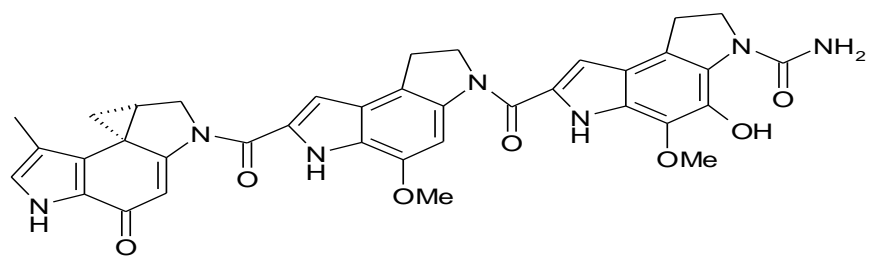

CC-1065<smiles>COC(=O)[C@]1(C)NC2=C(C1=O)[C@]1(C)CN(C(=O)c3cc4cc(OC)c(OC)c(OC)c4[nH]3)CC1=CC2=O</smiles>

(+)-Duocarmycin A<smiles>COC(=O)c1cc2c([nH]1)C(=O)C=C1N(C(=O)c3cc4cc(OC)c(OC)c(OC)c4[nH]3)C[C@H]3C[C@]123</smiles>

(+)-Duocarmycin SA<smiles>Cn1cc(NC(=O)c2cc(NC(=O)CNC(=N)Cl)cn2C)cc1C(=O)NCCC(=N)N</smiles> 


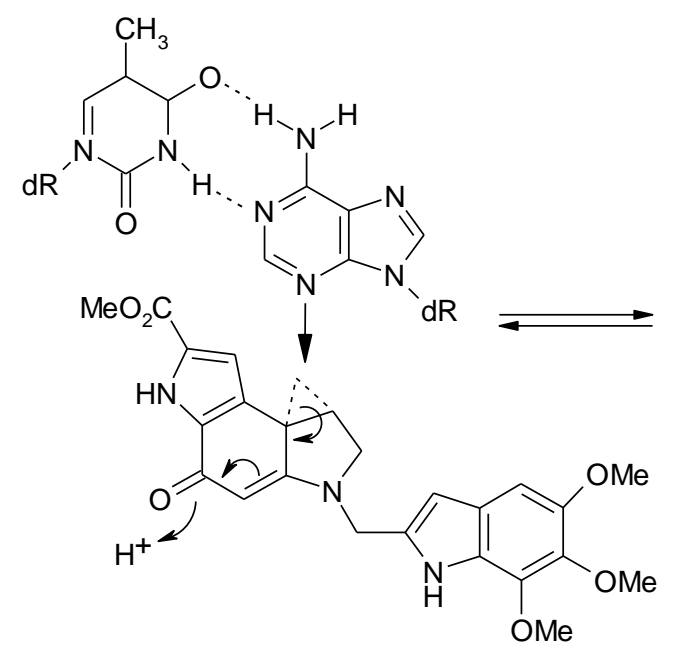

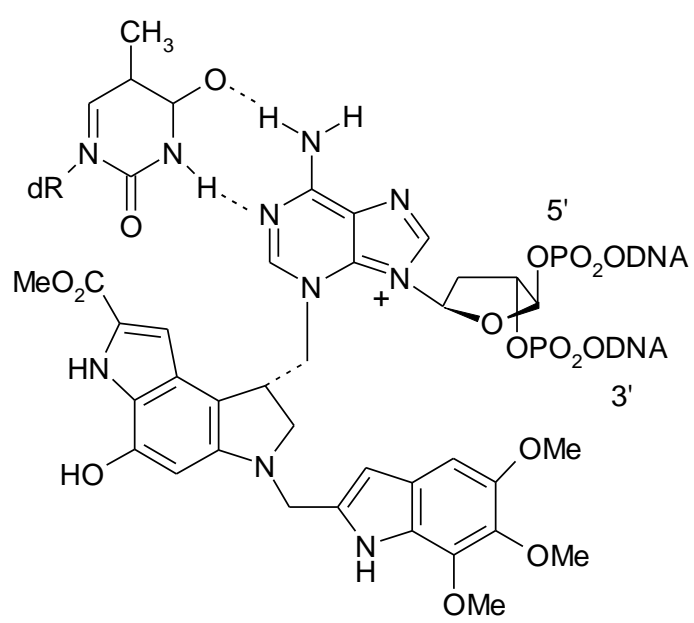<smiles>COc1cc2cc(CN3C[C](Cn4cnc(Nc5ccccc5)c5ncnc4-5)c4cc(O)c5[nH]c(C(C)=O)cc5c43)[nH]c2c(OC)c1OC</smiles><smiles>O=CC=CC(O)C[18O]O[Na]</smiles>

Şekil 1.11. Duocarmycin SA İle DNA Alkilasyonu

\section{Sonuç}

Bu çalışmada DNA'da hasar oluşturan, antikanser ilaç olarak kullanılan moleküllerin mekanizmalarını tartışılmıştır. Antikanser ilaçların etki mekanizmasını tam olarak anlamak, onları klinikte güvenilir ve etkili kullanmak için çok önemlidir. Günümüzde, kanser tedavisine immünoterapi ve hücre döngüsünün modülasyonu gibi yeni yaklaşımlar mevcuttur. DNA'ya bağlanabilen veya DNA hasarı oluşturabilen organik moleküllerin bu tedavi yöntemleriyle kombine kullanımları sinerjik etki göstermektedir. Küçük organik moleküllerin kanser tedavisindeki olumlu etkileri düşünüldüğünde, yeni molekül keşfi veya dizaynı ve sentezine yönelik çalışmaların uzun yıllar devam edeceği düşünülmektedir. 


\section{Kaynakça}

[1] Alberts, B., Johnson, A., Lewis, J., Raff, M., Roberts, K., Wlater, P. (2002). Molecular Biology of the Cell, fourth ed. Garland Science, Pp: 120-121. New York, Amsterdam.

[2] Baraldi, P.G., Preti, D., Fruttarolo, F., Tabrizi, M.A., Romagnoli, R. (2007). Hybrid molecules between distamycin A and active moieties of antitumor agents. Bioorganic and Medicinal Chemistry, 15: 17-35.

[3] Bennett, R. A. O., Swerdlow, P. S., Povirk, L. F. (1993). Spontaneous cleavage of bleomycininduced abasic sites in chromatin and their mutagenicity in mammalian shuttle vectors. Biochemistry. 32: 3188-95.

[4] Beria, I., Baraldi, P.G., Cozzi, P., Caldarelli, M., Geroni, C., Marchini, S., Mongelli, N., Romagnoli, R. (2004). Cytotoxic a-halogenoacrylic derivatives of distamycin A and congeners. Journal of Medicinal Chemistry, 47: 2611-2623.

[5] Breen, A. P., Murphy, J. A. (1995). Reactions of oxyl radicals with DNA. Free Radical Biology Medicine. 18(6): 1033-77.

[6] Bignell, G.R., Santarius, T., Pole, J.C.M., Butler, A.P., Perry, J., Pleasance, E., Greenman, C., Menzies, A., Taylor, S., Edkins, S., Campbell, P., Quail, M., Plumb, B., Matthews, L., McLay, K., Edwards, P.A.W., Rogers, J., Wooster, R., Futreal, P.A., Stratton, M.R. (2007). Architectures of somatic genomic rearrangement in human cancer amplicons at sequence level resolution. Genome Research, 17: 1296-1303.

[7] Caponigro, F., Lorusso, D., Fornari, G., Barone, C., Merlano, M., Airoldi, M., Schena, M., MacArthur, R., Weitman, S., Jannuzzo, M., Crippa, S., Fiorentini, F., Petroccione, A., Comis, S., Phase I. (2010). Dose-escalation study of brostallicin, a minor groove binder, in combination with cisplatin in patients with advanced solid tumors. Cancer Chemotherapy and Pharmacology, 66: 389-394.

[8] Chargaff, E., Vischer, E., Doniger, R., Green, C., Misani, F. (1949). The composition of the desoxypentose nucleic acids of thymus and spleen. The Journal of Biological Chemistry, 177: 405-416.

[9] Chambers, A.F., Groom, A.C., MacDonald, I.C. (2002). Metastasis: dissemination and growth of cancer cells in metastatic sites. Nature Reviews Cancer, 2: 563-572.

[10] Chatterji, T., M. Kızıl, K. Keerthi, G. Chowdhury, T. Pospilis ve K. S. Gates, (2003). Small Molecules That Mimic the Thiol-Triggered Alklating Properties Seen in the Natural Product Leinamycin. Journal of the American Chemical Society.125: 4996-4997.

[11] Çeken, B. (205). Sentetik maddeler ile DNA kesimi. Doktora Tezi, Fen Bilimleri Enstitüsü, Dicle Üniversitesi, Diyarbakır.

[12] Çeken, B. (2013). (+)-Duocarmycin Antibiyotiği Analoglarının Sentezlenmesi ve DNA Üzerine Etkilerinin Araştırılması, Doktora Tezi, Fen Bilimleri Enstitüsü, Dicle Üniversitesi, Diyarbakır. 
[13] Fonsega, G.C., Bickelhaupt, F.M., Snijders, J.G., Baerends, E.J. (1999). The nature of the hydrogen bond in DNA base Pairs: the role of charge transfer and resonance assistance. Chemistry-A European Journal, 5: 3581-3594.

[14] Gao, X., Mirau, P., Patel, D.J. (1992). Structure refinement of the chromomycin dimer- DNA oligomer complex in solution. The Journal of Molecular Biology, 223: 259-279.

[15] Gnarra, J.R., Tory, K., Weng, Y., Schmidt, L., Wei, M.H., Li, H., Latif, F., Liu, S., Chen, F., Duh, F.M., Lubensky, I., Duan, D.R., Florence, C., Pozzatti, R., Walther, M.M., Bander, N.H., Grossman, H.B., Brauch, H., Pomer, S., Brooks, J.D., Isaacs, W.B., Lerman, M.I., Zbar, B., Linehan, W.M. (1994). Mutations of the VHL tumour suppressor gene in renal carcinoma. Nature Genetics, 7: 85-90.

[16] Gottesman, M.M., Fojo, T., Bates, S.E., (2002). Multidrug resistance in cancer: role of ATPdependent transporters. Nature Reviews Cancer, 2: 48-58.

[17] Harman, D. (1962). Role of free radicals in mutation, cancer, aging, and the maintenance of life. Radiation Research, 16: 753-763.

[18] Kielkopf, C.L., White, S., Szewczyk, J.W., Turner, J.M., Baird, E.E., Dervan, P.B., Rees, D.C. (1998). A Structural basis for recognition of A.T and T.A base pairs in the minor groove of BDNA. Science, 282: 111-115.

[19] Lawley, P. D., Brookes, P. (1963). Further studies on the alkylation of nucleic acids and their constituent nucleotides. Biochemical Journal. 89, 127.

[20] Lerman, L.S., (1961). Structural Considerations in the Interaction of DNA and Acridines. Journal of Molecular Biology, 3: 18-30.

[21] Lown, J. W., Sim, S. K., Majumdar, K. C., Chang, R. Y. (1977). Strand scission of DNA by bound adriamycin and daunorubicin in the presence of reducing agents. Biochemical and Biophysical Research Communications. 76: 705.

[22] Lown, J.W. (1994). DNA recognition by lexitropsins, minor groove binding agents. Journal of Molecular Recognition. 7: 79-88.

[23] Neidle, S. (2001). DNA minor-groove recognition by small molecules. Natural Product Reports, 18: 291-309.

[24] Nelson, S.M., Ferguson, L.R,. Denny, W.A. 2007. Non-covalent ligand/DNA interactions: minor groove binding agents. Mutation Research, 623: 24-40.

[25] Pabo, C.O., Sauer, R.T. (1984). Protein-DNA recognition. Annual Review of Biochemistry, 53: 293-321.

[26] Pullman, A., Pullman, B. 1981. Molecular electrostatic potential of the nucleic acids. Quarterly Reviews of Biophysics. 14(3): 289-380.

[27] Sies, H. (1986). Biochemistry of Oxidative Stress. Angew. Chem. Int. Ed. Engl. 25:1058.

[28] Silverman, R. B. (1991). The Organic Chemistry of Drug Design and Drug Action. Academic Press. ILLINOIS. 
[29] Takeda, Y., Ohlendorf, D.H., Anderson, W.F., Matthews, B.W. 1983. DNA-binding proteins. Science, 221: 1020-1026.

[30] Tomasz, M. (1995). Mitomycin C: Small, fast and deadly (but very selective). Chemistry and Biology, 2: 575-579.

[31] Tu S.M. in: S.T. Rosen (Ed.). (2010). Heterogeneity of Cancer, Origin of Cancers, Springer, Pp. 129-136.

[32] Umezawa H, Maeda K, Takeuchi T, Okami Y. (1966). New antibiotics, bleomycin A and B. J Antibiot (Tokyo). 19(5): 200-9.

[33] Urruticoechea, A., Alemany, R., Balart, J., Villanueva, A., Viñals, F., Capellá, G. (2010). Recent advances in cancer therapy: an overview. Current Pharmaceutical Design, 16: 3-10.

[34] Von Sonntag, C., Hagen,U., Schon-Bopp., A., Schulte-Frohlinde, D. (1981). Radiation induced strand breaks in DNA: Chemical and enzymatic analysis of end gropus and mechanistic aspects. Advances in Radiation Biology. 9: 109.

[35] Watson, J.D., Crick, F.H.C. (1953). A structure for deoxyribose nucleic acid. Nature. 171, 737-738.

[36] Watson, J.D., Crick, F.H.C. (1993). Molecular Structure of Nucleic Acids: A Structure for Deoxyribose Nucleic Acid. The Journal of the American Medical Association. 269: 1966-1967.

[37] Weiling, F. (1991). Historical study: Johann Gregor Mendel 1822-1884. American Journal of Medical Genetics, 40: 1-25.

[38] Wing, R., Drew, H., Takano, T., Broka, C., Tanaka, S., Itakura, K., Dickerson, R. (1980). Crystal structure analysis of a complete turn of B-DNA. Nature, 287: 755-758.

[39] Yap, K.Y.L, Chan, A., Chui, W.K., Chen, Y.Z. (2010). Cancer informatics for the clinician: an interaction database for chemotherapy regimens and antiepileptic drugs. Seizure, 19: 59-67. 